\title{
National consensus on oncoplastic breast conserving surgery in Turkey: position paper for the standardization of surgical practice
}

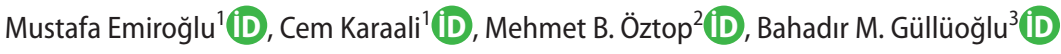 \\ ${ }^{1}$ Clinic of General Surgery, Izmir Tepecik Education and Research Hospital, Izmir, Turkey \\ ${ }^{2}$ Izmir Provincial Health Directorate, Health Directorate, İzmir, Turkey \\ ${ }^{3}$ Department of General Surgery, Marmara University School of Medicine, Istanbul , Turkey
}

\begin{abstract}
Objective: The algorithms that define most of the application of oncoplastic breast conserving surgery (OBCS) in breast cancer patients are not clearly defined. Therefore, a consensus survey was conducted between the leading and experienced breast surgeons and oncoplastic breast surgeons in Turkey on the controversial areas of oncoplastic breast surgery.

Material and Methods: This consensus survey was carried out on-line through the Consensus software program (www.consensuss.com) under the roof of Turkish Federation of National Societies for Breast Diseases (TFNSBD). After finalizing each proposition, web-based remote access consensus process was performed on the Likert scale using Delphi method with the Consensus (www.consensuss.com) software program. Through the related software, an invitation was sent to 111 people who had at least 5 years of general surgery expertise in Turkey, and who devoted more than $50 \%$ of their daily clinical practice to the treatment and surgery of breast diseases.

Results: Sixty-two out of 111 people accepted to participate in the panel and made an on-line evaluation. According to the consensus results; Lumpectomy area should be done by placing the clips on at least four walls of the cavity, if the margin of the tumor is clear in central tumors, the distance between the tumor and the nipple is not significantly important, oncoplastic techniques may be used in patients with locally advanced breast cancer after neoadjuvant chemotherapy, in patients who have macromastia with ductal carcinoma in situ or breast cancer, OBCS techniques can be performed, and OBCS should be evaluated in terms of breast aesthetics. After OBCS, re-excision can be performed at a re-do setting in cases with involved surgical margins.
\end{abstract}

Conclusion: Our consensus results may provide a basis for the development of some standards in OBCS.

Keywords: Oncoplastic breast conserving surgery, standardization, consensus

Cite this article as: Emiroğlu $M$, Karaali $C$, Öztop $M B_{\text {, }}$ Güllüoğlu BM. National consensus on oncoplastic breas conserving surgery in Turkey: position paper for the standardization of surgical practice. Turk J Surg 2020; 36 (3): 271 277

Corresponding Author

Cem Karaali

E-mail: cemkaraali@gmail.com

Received: 09.10.2019

Accepted: 27.02 .2020

Available Online Date: 28.09 .2020

- Copyright 2020 by Turkish Surgical Society Available online at www.turkjsurg.com

DOI: $10.47717 /$ turkjsurg.2020.4639

\section{INTRODUCTION}

Oncoplastic breast conserving surgery (OBCS) is one of the significant procedural innovations in the surgical treatment of breast cancer. This recent change in surgical practice is the result of a patient-centered trend of treatment (1).

Clinical guidelines are written documents to which physicians and other care providers frequently refer for better health care. Guidelines are required to be evidence-based (2). However, when considering patient care pathway in a certain health problem or practice such as surgical treatment of breast cancer, it is unfortunate that not every time the evidence is straightforward. For those instances, consensus procedure is recommended in which expert opinion is collected to guide the care. Consensus is advised to be sought when there is no satisfactory evidence for the aforementioned issue. This happens when there is no reported data on the issue or there are more than one but contradictory to each other or when the collected data is not applicable for the respective population (3).

So far, no regional or global comprehensive OBCS practice guideline or consensus has been released. Therefore, today, surgeons empirically shape their practice in line with their own knowledge and experience $(1,4,5)$. Standards of practice related to OBCS are not explicitly defined. Neither national nor international consensus has been reached on all aspects of surgical practice on this field yet. 
Therefore, currently there is a pressing need for a contemporary OBCS guideline. Here in this position paper, we report the results of a consensus procedure on OBCS by collecting opinions from eminent Turkish breast surgeons who have considerable amount of experience on the field. All recommendation statements for voting were formulized from those issues with no satisfactory evidence, hence regarded as gap-of-knowledge.

\section{MATERIAL and METHODS}

Consensus procedure was structured according to the Delphi method (6). We used a commercially available consensus software program (www.consensuss.com; Pleksus, Istanbul, Turkey) to run the whole procedure on-line.

Turkish Federation of the National Societies for Breast Diseases (TFNSBD) fully endorsed and sponsored the consensus process.

As the initial step, a consensus development committee (CDC) was constituted. Twelve breast surgeons who were among the executive members of TFNSBD at the time were assigned as CDC members. CDC initially drafted 14 statements as clinical recommendations in areas where they regarded there is gap of knowledge. After rigorous review of these statements, they were lowered to 10.

All regulatory preferences of the consensus procedure were decided a priori and necessary instructions were given accordingly to the user interface of the programme.

Candidate panelists were chosen from Turkish Society of Surgery's Members Registry according to the criteria as described below:

a. Surgical oncologists who have experience on breast surgery for at least 10 years.

b. Having experience on OBCS (those currently performing OBCS or ad previous certification on OBCS).

c. Currently working or recently worked at a surgical oncology unit in tertiary hospitals for minimum 5 years.

d. Currently practicing breast surgery at minimum 50\% of his/ her clinical time.

E-mail invitation was sent to those surgeons who fulfilled the above criteria in which the aim, scope and the structure of the procedure was explained. Those who accepted to attend the online sessions were assigned as "Panelist".

Structurally, consensus voting was performed by using a 9-item Likert scale where 1, 2, 3 represented "I agree", 7, 8, 9 represented "I disagree" and 4, 5, 6 represented "abstained" for the asked recommendation.

Criteria for decisions on recommendations were as follow:

"Quorum": Threshold of overall voting (attendance) rate for reaching a decision on any recommendation was determined to be $80 \%$, regardless of the voting result.
"Consensus Reached-Endorsed as a Recommendation": If 70\% or more panelists voted for "I agree", that recommendation was regarded as "endorsed" by the consensus panel.

"Consensus Reached-Rejected as a Recommendation": In case of having less than $70 \%$ "I agree" voting, if $25 \%$ or more panelists voted for "I disagree", that recommendation was regarded as "rejected" by the consensus panel. If votes for both "I agree" and "I disagree" exceeded the thresholds of $70 \%$ and $25 \%$, respectively, the decision was regarded according to the one whichever has the majority.

"Consensus Not Reached-Inconclusive": In those recommendations where less than $80 \%$ of the panelists sent their opinion after overall 2 rounds, the decision was regarded as "consensus not reached-inconclusive". Also, if both votes for "I agree" and "I disagree" did not exceed the thresholds of $70 \%$ and $25 \%$, respectively, the decision was again regarded as "consensus not reached-inconclusive".

In each round, the set of recommendations was sent by e-mail to all panelists who accepted to attend the on-line consensus. In each round, one week duration was given to the panelists to complete their voting. In those recommendations where a decision was not reached according to the criteria, next round of voting was done. Total rounds of voting were determined to be 2. If any of the a priori determined thresholds was reached in any round, the consensus process was regarded to be completed for that particular recommendation. On the other hand, if any decision was not reached at the end of second round, result was regarded as "consensus not reached-inconclusive" for that recommendation. No statistical analysis was done. Only descriptive voting results were given as raw data.

\section{RESULTS}

The invitation for on-line consensus procedure was sent to 111 surgeons who fulfilled the selection criteria. Sixty-two (56\%) agreed to participate in the consensus voting (Table 1). Consensus panel was commenced on 4 July 2016100 and finished on 12 August 2016

The panelists reached a consensus on 7 recommendations after the first round, 2 after the second. Only for one recommendation, the panelists did not reach a consensus due to under threshold voting counts for both "I agree" and "I disagree" options despite having the quorum until the final second round.

\section{Voting Results}

Recommendation no 1: "For breast boost irradiation following OBCS, marking the lumpectomy cavity should be done by placing clips on at least four walls of the cavity."

First round: 62 (100\%) panelists attended the voting and 37 (60\%) of them favored the recommendation, whereas 10 (16\%) disagreed and 15 (24\%) remained abstain. 
Result: Consensus Reached-Endorsed as a Recommendation.

Recommendation no 8: "After OBCS, re-excision can be performed at a re-do setting in cases with involved surgical margins."

First round: 62 (100\%) panelists attended the voting and 47 (76\%) of them favored the recommendation, whereas 2 (3\%) disagreed and 13 (21\%) remained abstain.

Result: Consensus Reached-Endorsed as a Recommendation.

Recommendation no 9: "For surveillance of young breast cancer patients with dense tissue who have undergone volume displacement and/or replacement surgery, breast magnetic resonance imaging (MRI) should be supplemented to standard mammography ( \pm breast ultrasonography) for routine imaging of the breasts."

First round: 62 (100\%) panelists attended the voting and 33 (53\%) of them favored the recommendation, whereas 14 (23\%) disagreed and 15 (24\%) remained abstain.

Second round: 57 (92\%) panelists attended the voting and 46 (81\%) of them favored the recommendation, whereas 6 (11\%) disagreed and 5 (9\%) remained abstain.

Result: Consensus Reached-Endorsed as a Recommendation.

Recommendation no 10: "In those breast cancer patients planned to undergo OBCS, breast volume should be measured before surgery."

First round: 62 (100\%) panelists attended the voting and 34 (55\%) of them favored the recommendation, whereas 6 (10\%) disagreed and 22 (35\%) remained abstain.

Second round: 57 (92\%) panelists attended the voting and 32 (56\%) of them favored the recommendation, whereas 5 (9\%) disagreed and 20 (35\%) remained abstain.

Result: Consensus Not Reached-Inconclusive.

\section{DISCUSSION}

In this first consensus from Turkey on OBCS, ten statements were voted. All statements were formulized from controversial issues chosen from breast cancer patients' care pathway by the CDC assigned by the National Federation (TFNSBD). As a result, nine statements were favored by the majority of 62 opinion leaders who are dedicated and experienced breast surgeons authenticated by their case load and academic level. Only in one statement the voters did not reach a consensus.

This is the first consensus on OBCS in Turkey and as far we know, one of the few in the world. We used a contemporary methodology for the whole process, as described previously (3). We established strict criteria for panelist nominations, and all attendants were expert surgical oncologists with adequate expertise on this particular field and whose names were in agreement overall. Due to the practicability of the software package, the consensus went uneventful and fast. All of the terms of the consensus procedure were decided a priori and due to technical aspect of the on-line voting system, all the results were obtained automatically therefore, decreasing human error. Almost all decisions were reached at the end of the first round. Only one recommendation was needed to be voted in two rounds but could not reach a consensus at the end.

In this consensus procedure, we had certain limitations. We could not discuss all controversial issues for OBCS and put them for voting. Furthermore, although they are also the part of the team, plastic and reconstructive surgeons were not invited for the voting process. Another potential limitation was the low acceptance rate after sending the initial invitation to all breast cancer-related surgical oncologists. Although more than half of the invited surgeons attended the voting, the overall representation rate may be considered low.

Since its first conceptual description in the early 1990s, many different OBCS techniques have been described and classified in different terminology $(1,4,7,8)$. Currently, variations in surgical practice do not get any widely accepted standardization. This still causes nonuniform practice among surgeons and lack of common language $(7,9,10)$. One of the gaps-in knowledge for OBCS is the adequate marking of the resection cavity since local recurrences after lumpectomy are usually in the field of lumpectomy.

Furthermore, boost irradiation of the tumor bed in addition to whole breast has been found to decrease local recurrence (11). However, tumor area is significantly being displaced with OBCS. Marking the cavity may become a challenging issue especially during OBCS, such as wise pattern reductions. Discussions still continue on how many walls should be clipped after lumpectomy before reshaping $(9,10,12)$. Despite different practice patterns, some surgeons find adequate to place only one clip on the base of the cavity (13). Here in our panel, opinion leaders reached a consensus with the majority favoring the recommendation for marking the cavity by placing clips on minimum 4 walls.

Preservation of the NAC during breast cancer surgery is still a matter of debate. There are surgeons who advocate NAC-sparing surgery if intraoperative frozen section assessment does not reveal tumor involvement at the retro-areolar resection margin without taking the distance between the tumor and the NAC complex under consideration (10). On the other hand, some suggest that NAC sparing surgery should not be attempted if the distance is less than a certain length (14). In this consensus, the surgeons were in agreement for the feasibility of performing NAC-sparing surgery where the distance between the tumor and NAC should not be considered as a selection criterion as long as the surgical 241 margin is tumor-free after intraoperative histologic evaluation. 
Again, another controversial issue is the safety of BCS in those patients with tumors down-staged after NST. Previous reports have shown that up-front OBCS techniques can safely be performed to resect large tumors which are not feasible for conventional BCS $(15,16)$. Therefore, OBCS also seems to be a relevant choice for patients who receive NST for locally advanced cancer. It has been shown that OBCS can be performed safely in patients after NAC without an increased complication risk or adjuvant treatment delays (17). Furthermore, OBCS has been found to provide satisfactory breast cosmetic outcome in these patients (18). Along with these individual findings, also in our consensus panel, most surgeons supported the statement in which OBCS is recommended as one of the valid options in patients with locally advanced cancer who received NST and downstaged.

Apart from its association with shoulder and neck pain in patients (19), dose distribution problems during whole breast irradiation make macromastia to be regarded as one of the relative contraindications for BCS (20). Therefore, OBCS such as tumor resection with a reduction mammoplasty technique in patients with macromastia would obviate such limitations. One of the gaps-in-knowledge in this context is the essentiality of performing concomitant bilateral reduction at both sides including contralateral healthy breast. It is reasonable to expect that macromastia-related symptoms may be corrected as a whole by such intervention on both sides. It has been previously shown that unilateral wise-pattern reduction mammoplasty improves patient-related outcomes such as patient satisfaction and quality-of-life measures in breast cancer patients $(12,21)$. However, it is not clear yet if bilateral reduction mammoplasty provides any better patient-related outcome in patients with unilateral breast cancer. In this consensus panel, the panelists voted overwhelmingly favoring concurrent contralateral breast reduction in patients with unilateral breast cancer and bilateral macromastia.

There are controversial findings of the clinical outcome of OBCS techniques in DCIS patients. Findings of some studies do not support implementing oncoplastic surgery in these patients $(22,23)$, whereas in others it has been found that OBCS techniques with larger resections can be safely performed without compromising oncological outcome $(4,10,24)$. In our panel, the recommendation which advocates performing OBCS in DCIS patients as long as the margin clearance is provided was endorsed with consensus.

It has been suggested that the outcome of OBCS should also be assessed from aesthetic perspective. Breasts are gender-specific organs which represent feminity and provide the integrity of sexual well-being in women. Most think that along with survival, aesthetic outcome after breast cancer surgery has paramount importance $(9,10)$. Also, some authors think that the assessment should be done when edema and swellings are minimum after surgery $(25,26)$. However, there is still a controversy regarding the necessity of routine aesthetic evaluation and its timing after $\operatorname{OBCS}(9,10,25,26)$. Therefore, in this current consensus, we also asked breast surgeons for their opinions whether making aesthetic evaluation a standard component of outcome after $\mathrm{OBCS}$ is necessary. The panel overwhelmingly agreed that aesthetic assessment should be done after surgery as one of the treatment outcome indicators. In further voting, the panelists agreed that this assessment should not be done until all adjuvant radiotherapy and chemotherapy are completed and not before postoperative $6^{\text {th }}$ month.

Margin positivity is one of the most significant determinants of local recurrence after lumpectomy in breast cancer patients (27). However, despite every effort to obtain clear margins, permanent pathology assessment may reveal tumor involvement at surgical margins. In this circumstance, some advocate performing total mastectomy $(5,9,28)$. On the other hand, in order to maintain the integrity of the breast, re-resection of cavity walls was also recommended in suitable cases $(10,19,29)$. Therefore, in order to clarify this issue in OBCS patients, we asked the panel their opinion on this issue. As a result, the majority endorsed re-resection of the involved margins where it seems appropriate and feasible.

Young patients commonly have breast tissue with high-density. This is particularly important when assessing the breasts in patients after partial mastectomy for in-breast local recurrence screening (30). Since OBCS includes breast re-modelling with volume replacement and displacement which are more complex and extensive techniques than conventional BCS, fibrosis and fat necrosis have been found to occur more commonly especially when those patients receive irradiation (31). Therefore, ruling out cancer recurrence has upmost importance in these patients. Interpretations of mammography and ultrasonography have been reported to be challenging after OBCS as well (32). Therefore, the role of breast MRI in young patients undergoing OBCS is not clear $(21,32)$. However, in this consensus, the majority of the panelists agreed to advocate using breast MRI in young breast cancer patients for surveillance after treatment.

In the current panel, there was only one recommendation that did not attain an agreement amongst the panelists. It is believed that tumor size to breast volume ratio is important for determining the type of surgery. In those patients, when the resection volume is expected to be greater than 20\%, OBCS, instead of conventional BCS, seems to be a valid option to avoid mastectomy (10,33). Also, associated macromastia may affect the surgeon's choice for oncoplastic technique $(10,12)$. However, there is no generally accepted practice for measuring the breast volume before the surgery. Most surgeons perform breast surgery by estimation of the breast volume and its ratio 
to the tumor size either empirically or by various non-uniform methods (34). After two rounds of voting, the consensus panel did not reach a majority either for endorsement or rejection of performing routine measurement of breast volume at both sides before the surgery. So, this issue remained inconclusive in the current panel.

\section{CONCLUSION}

According to the current consensus results, Turkish surgeons were in agreement for almost all of the chosen controversial issues in OBCS. The simplicity and speed of the consensus methodology and its results showed that many controversial issues may be discussed and solved by collecting expert opinions with electronic tools such as ours. The current panel which gathered significant amount of experts' opinions on-line provided temporary solutions to some of the controversial issues on OBCS until having satisfactory further evidence from clinical studies.

\section{Ethics Committee Approval: Not relevant}

Peer-review: Externally peer-reviewed.

Author Contributions: Concept - M.E., B.M.G., M.B.Ö., C.K.; Design - M.E. B.M.G.; Supervision - M.E., B.M.G.; Data Collection and/or Processing - C.K., M.B.Ö., Analysis and Interpretation - M.E., B.M.G.; Literature Review - M.E., C.K.; Writing Manuscript - M.E., B.M.G., C.K.; Critical Reviews - B.M.G., M.B.Ö

Conflict of Interest: The authors have no conflicts of interest to declare.

Financial Disclosure: The authors declared that this study has received no financial support.

\section{REFERENCES}

1. Clough KB, Ihrai T, Oden S, Kaufman G, Massey E, Nos C. Oncoplastic surgery for breast cancer based on tumour location and a quadrant per-quadrant atlas. Br J Surg 2012; 99: 1389-95. [CrossRef]

2. Atkinson M. Introduction. In: How to write a guideline: From start to finish. Bowker R, Lakhanpaul M, Atkinson M, Armon K, MacFaul R, Stephenson T. 1 ed. Toronto: Churchill-Livingstone Elsevier; 2008. pp. 1-11. [CrossRef]

3. Armon K. Consensus processes. In: How to write a guideline: From start to finish. Bowker R, Lakhanpaul M, Atkinson M, Armon K, MacFaul R, Stephenson T. 1 ed. Toronto: Churchill-Livingstone Elsevier; 2008 pp. 77-84. [CrossRef]

4. Weber WP, Soysal SD, El-Tamer M, Sacchini V, Knauer M, Tausch C, et al. First international consensus conference on standardization of oncoplastic breast conserving surgery. Breast Cancer Res Treat 2017; 165: 139-49. [CrossRef]

5. Kronowitz SJ, Hunt KK, Kuerer HM, Strom EA, Buchholz TA, Ensor JE, e al. Practical guidelines for repair of partial mastectomy defects using the breast reduction technique in patients undergoing breast conservation therapy. Plast Reconstr Surg 2007; 120: 1755-68. [CrossRef]

6. Jones J, Hunter D. Consensus methods for medical and health services research. BMJ 1995; 311:376-80. [CrossRef]

7. McIntosh J, O'Donoghue JM. Therapeutic mammaplasty: a systematic review of the evidence. Eur J Surg Oncol 2012; 38: 196-202. [CrossRef]
8. Piper M, Peled AW, Sbitany H. Oncoplastic breast surgery: current strategies. Gland Surg 2015; 4: 154-63. [CrossRef]

9. Haloua MH, Krekel NMA, Winters HAH, Rietveld DHF, Meijer S, Bloemers FW, et al. A systematic review of oncoplastic breast-conserving surgery: current weaknesses and future prospects. Ann Surg 2013; 257: 609-20. [CrossRef]

10. Emiroğlu M, Sert I, Inal A. The role of oncoplastic breast surgery in breast cancer treatment. J Breast Health 2015; 11: 1-9. [CrossRef]

11. Jones HA, Antonini N, Hart AAM, Peterse JL, Horiot JC, Collin F, et al. Impact of pathological characteristics on local relapse after breast conserving therapy: a subgroup analysis of the EORTC boost versus no boost trial. J Clin Oncol 2009; 27: 4939-47. [CrossRef]

12. Munhoz AM, Montag E, Gemperli R. Current aspects of therapeutic reduction mammaplasty for immediate early breast cancer management: An update. World J Clin Oncol 2014; 5: 1-18. [CrossRef]

13. Emiroğlu M. Treatment approaches for breast cancer surgery in European Academy of Senology. J Tepecik Edu Res Hosp 2015; 25: 69-70. [CrossRef]

14. Mallon P, Feron JG, Couturaud B, Fitoussi A, Lemasurier P, Guihard T, et al. The role of nipple-sparing mastectomy in breast cancer: a comprehensive review of the literature. Plast Reconstr Surg 2013; 131: 969-84. [CrossRef]

15. Bogusevicius A, Cepuliene D, Sepetauskiene E. The integrated evaluation of the results of oncoplastic surgery for locally advanced breast cancer. Breast J 2014; 20: 53-60. [CrossRef]

16. Emiroglu M, Sert I, Karaali C, Aksoy SO, Ugurlu L, Aydın C. The effectiveness of simultaneous oncoplastic breast surgery in patients with locally advanced breast cancer. Breast Cancer 2016; 23: 463-70. [CrossRef]

17. Adamson K, Chavez-MacGregor M, Caudle A, Smith B, Baumann D, Liu J, et al. Neoadjuvant chemotherapy does not increase complications in oncoplastic breast-conserving surgery. Ann Surg Oncol 2019; 26: 2730-7. [CrossRef]

18. YoussefMMG, Namour A, Youssef OZ, Morsi A. Oncologic and cosmetic outcomes of oncoplastic breast surgery in locally advanced breast cancer after neoadjuvant chemotherapy, experience from a developing country. Indian J Surg Oncol 2018; 9: 300-6. [CrossRef]

19. Dundas KL, Atyeo J, Cox J. What is a large breast? Measuring and categorizing breast size for tangential breast radiation therapy. Australas Radiol 2007; 51: 589-93. [CrossRef]

20. Moody AM, Mayles WP, Bliss JM, et al. The influence of breast size on late radiation effects and association with radiotherapy dose inhomogeneity. Radiother Oncol 1994; 33: 106-112. [CrossRef]

21. Emiroglu M, Salimoglu S, Karaali C, Sert I, Gungor O, Sert F, et al. Oncoplastic reduction mammoplasty for breast cancer in women with macromastia: Oncological long-term outcomes. Asian J Surg 2017; 40: 41-7. [CrossRef]

22. Losken A, Dugal CS, Styblo TM, Carlson GW. A meta-analysis comparing breast conservation therapy alone to the oncoplastic technique. Ann Plast Surg 2014; 72: 145-9. [CrossRef]

23. Schaverien MV, Raine C, Majdak-Paredes E, Dixon JM. Therapeutic mammaplasty: extending indications and achieving low incomplete excision rates. Eur J Surg Oncol 2013; 39: 329-33. [CrossRef]

24. Franceschini G, Terribile D, Magno S, Fabbri C, Accetta C, Di Leone A, et al. Update on oncoplastic breast surgery. Eur Rev Med Pharmacol Sci 2012; 16: 1530-40. [CrossRef] 
25. Emiroglu M, Karaali C, Salimoglu S, Sert I, Aydın C. Oncoplastic reduction mammoplasty for breast cancer in women with macromastia: long term aesthetic, functional and satisfaction outcomes. Contemp Oncol (Pozn) 2016; 20: 256-60. [CrossRef]

26. Cardoso MJ, Cardoso JS, Vrieling C, Macmillan D, Rainsbury D, Heil J, et al. Recommendations for the aesthetic evaluation of breast cancer conservative treatment. Breast Cancer Res Treat 2012; 135: 629-37. [CrossRef]

27. Houssami N, Macaskill P, Marinovich ML, Morrow M. The association of surgical margins and local recurrence in women with early-stage invasive breast cancer treated with breast-conserving therapy: a meta-analysis. Ann Surg Oncol 2014; 21: 717-30. [CrossRef]

28. Gulcelik MA, Dogan L, Yuksel M, Camlibel M, Ozaslan C, Reis E. Comparison of outcomes of standard and oncoplastic breast-conserving surgery. J Breast Cancer 2013; 16: 193-7. [CrossRef]

29. Rose M, Manjer J, Ringberg A, Svensson H. Surgical strategy, methods of reconstruction, surgical margins and postoperative complications in oncoplastic breast surgery. Eur J Plast Surg 2014; 37: 205-14. [CrossRef]
30. Houssami N, Cho N. Screening women with a personal history of breast cancer: overview of the evidence on breast imaging surveillance. Ultrasonography 2018; 37: 277-87. [CrossRef]

31. Rozen WM, Ashton MW. Radiotherapy and breast reconstruction: oncology, cosmesis and complications. Gland Surg 2012; 1: 119-27. [CrossRef]

32. Kim H, Kang BJ, Kim SH, Kim HS, Cha ES. What we should know in mammography after reduction mammoplasty and mastopexy? Breast Cancer 2015; 22: 391-8. [CrossRef]

33. Kayar R, Civelek S, Cobanoglu M, Gungor O, Catal H, Emiroglu M. Five methods of breast volume measurement: a comparative study of measurements of specimen volume in 30 mastectomy cases. Breast Cancer (Auckl) 2011; 5: 43-52. [CrossRef]

34. Xi W, Perdanasari AT, Ong Y, Han S, Min P, Su W, et al. Objective breast volume, shape and surface area assessment: a systematic review of breast measurement methods. Aesthetic Plast Surg 2014; 38: 1116-30. [CrossRef]

\title{
ORIJINAL ÇALIŞMA-ÖZET
}

Turk J Surg 2020; 36 (3): 271-277

\section{Türkiye'deki onkoplastik meme koruyucu cerrahi uygulamaları hakkında ulusal konsensüs: cerrahi pratik uygulamaların standardizasyonu için öneriler}

\author{
Mustafa Emiroğlu ${ }^{1}$, Cem Karaali ${ }^{1}$, Mehmet B. Öztop ${ }^{2}$, Bahadır M. Güllüoğlu ${ }^{3}$ \\ 1 İzmir Tepecik Eğitim ve Araştırma Hastanesi, Genel Cerrahi Kliniği, İzmir, Türkiye \\ 2 İzmir II Sağlık Müdürlüğ̈ü, İzmir, Türkiye \\ ${ }^{3}$ Marmara Üniversitesi Tıp Fakültesi, Genel Cerrahi Anabilim Dalı, İstanbul, Türkiye
}

\section{ÖZET}

Giriş ve Amaç: Meme kanseri hastalarında onkoplastik meme koruyucu cerrahi (OMKC) uygulamalarının çoğunu tanımlayan algoritmalar net değildir. Bu nedenle ülkemizin önde gelen ve konularında deneyimli meme cerrahları ve onkoplastik meme cerrahları arasında onkoplastik meme cerrahisindeki tartışmalı alanlar hakkında bir konsensüs düzenlenmiştir.

Gereç ve Yöntem: Bu konsensüs Türkiye Meme Hastalıkları Dernekleri Federasyonu (TMHDF) çatısı altında on-line Consensuss (www.consensuss. com) yazılımı aracılığı ile gerçekleştirildi. Her bir önermeye son şeklinin verilmesinden sonra Consensuss (www.consensuss.com) yazılım programı ile web tabanlı uzaktan erişimli konsensüs işlemi Delphi metodu kullanılarak Likert skalası üzerinden gerçekleştirildi. Türkiye'de çalışan en az 5 yıllık genel cerrahi uzmanı olup günlük klinik uygulamalarının \%50'sinden fazlasını meme hastalıklarının tedavisine ayıran 111 kişiye ilgili yazılım aracılığı ile davet yollandı.

Bulgular: Davet edilen 111 kişiden 62'si panele katılmayı kabul etmiş ve on-line değerlendirme yapmıştır. Konsensüs sonuçlarına göre; lumpektomi kavitesine en az dört klps konulmalıdır, santral tümörlerde temiz cerrahi sınır elde edilmesi yeterlidir, neoadjuvan kemoterapi sonrası OMKC uygulanabilir, OMKC kanserli veya duktal karsinoma in-situ hastalığına sahip makromastili hastalara uygulanabilir, OMKC estetik sonuçları açısından değerlendirilmelidir. OMKC sonrası pozitif sınır gelmesi durumunda re-eksizyon yapılabilir.

Sonuç: Konsensüs sonuçlarımız OMKC'de bazı standartların gelişmesine temel oluşturabilir.

Anahtar Kelimeler: Onkoplastik meme koruyucu cerrahi, standardizasyon, konsensüs

Doi: $10.47717 /$ turkjsurg.2020.4639 